\title{
Food and body culture in the aging process
}

\begin{abstract}
The aging process occurs from the moment of conception, however, it is around of thirty years old that the physiological decline becomes visible and sensitive, from the interaction between genetic and environmental factors, in addition to other socio-cultural variables. Just as genetics influences longevity, it also influences the way we get old from an aesthetic point of view. The cult of the "ideal" body, both in its composition and in its aesthetics, becomes something unattainable in view of the different genetic and cultural background that we acquired through our previous generations, sometimes giving rise to the 'gerontophobia' phenomenon. The urge to remain young comes up against not only the aesthetic frontier, but also the health frontier, where physical activity and food habits can be included, this last one, built by our social, cultural and identity marks. The objective of the present narrative review is to discuss cultural aspects related to food, body, health and disease and their association with aging.
\end{abstract}

Keywords: aging, culture, food habits, longevity, nutrition

\author{
Volume 5 Issue 6 - 2020
}

\author{
Nicole Debia,' Nadia Dumara Ruiz Silveira, ${ }^{2}$ \\ Maria Helena Villas Bôas Concone ${ }^{3}$ \\ 'Professor, Nutrition Department, Faculdade de Floriano-FAESF, \\ Brazil \\ ${ }^{2}$ Professor, Education Department, Pontifícia Universidade \\ Católica de São Paulo, Brazil \\ ${ }^{3}$ Professor, Social Sciences Department, Pontifícia Universidade \\ Católica de São Paulo - PUC-SP, Brazil
}

\author{
Correspondence: Nicole Debia, Professor, Nutrition \\ Department, Faculdade de Floriano - FAESF, Floriano-PI, Brazil, \\ Email nicoleebia@hotmail.com
}

Received: November 03, 2020 | Published: November 27, 2020

\section{Introduction}

The aging process occurs from the moment of conception, however, it is around of thirty years old that the physiological decline becomes visible and sensitive. ${ }^{1}$ There are several theories that work with different hypotheses about the aging process, among them, the genetic theory understands this phenomenon as a continuity of intrinsic biological processes related to DNA damage and decline of the immune system, for example. On the other hand, we have the stochastic theory that postulates that aging depends mainly on the accumulation of environmental factors such as pollution, inadequate nutrition, exposure to viruses and bacteria, among others. ${ }^{2}$ We find it more acceptable the interaction between both theories, in addition to other socio-cultural variables such as family support, spirituality, resilience and social engagement. ${ }^{3}$

Aging is part of the trajectory of all humans and when admitted as a natural process of life, becomes beneficial to the development, maturation and acceptance of old age for all those who have the privilege of living it. This process must be understood as a different phenomenon from longevity. We will all grow old, but only a few of us will have an exceptional lifespan. In addition, longevity suffers a strong genetic influence in childhood and in the extremes of old age, and this influence may be responsible for the emergence of chronic diseases that manifest during aging, such as neoplastic processes, osteoporosis and dementia. ${ }^{4}$

Just as genetics influences longevity, it also influences the way we get old from an aesthetic point of view. Brazil is understood by very wide miscegenation and that gives rise to individuals as heterogeneous in their physical aspect as old age is heterogeneous. In this way, the cult of the "ideal" body, both in its composition and in its aesthetics, becomes something unattainable in view of the different genetic and cultural background that we acquired through our previous generations.

In building the body, we also build our identity. And in that impulse to build a beautiful and always young body, the 'gerontophobia' phenomenon arises, which consists of the fear of aging. This fear and also the fear of death - has been with mankind for so long, that in the Old Testament there are records that the subjects of King David brought a beautiful young virgin to live close to his bed, because the belief that this coexistence would make him rejuvenate and prolong his life. ${ }^{5}$

Longevity has always been something that the human race wanted to achieve, but it must be thought of as an event that goes beyond the increase in years lived. Other issues must be considered to make sense, such as autonomy and life goals. It has been found that the more the individual becomes long-lived, the more limited and fragile he is. According to Papaléo Netto and Kitadai, ${ }^{6}$ functional reduction can reach $40 \%$ in advanced old age, however when life conditions are successful, physical and mental disability are reduced.

In addition to the environmental determinants mentioned above, other agents can also increase the capacity of those who are getting old, including the physical environment, economic factors, social and health services. ${ }^{7}$ The urge to remain young comes up against not only the aesthetic frontier, but also the health frontier, where physical activity and food can be included.

In this regard, adequate nutrition contributes to improve the quality of life and longevity, by preventing diseases or controlling installed ones. Some nutrients still have the ability to reduce cell damage, delaying the aging process. ${ }^{8}$

We bring in our food habits and our body all the social, cultural and identity marks and, when we try and can't change it in its essence, we reveal failure. In different cultures, the diet and values associated with each body type change substantially. While historically the woman with more weight was considered more attractive, more passive and showed greater purchasing power, in modern life this same body has shown an inability to control its own appetite and herself. ${ }^{9}$

Thus, the objective of the present narrative review is to discuss cultural aspects related to food, body, health and disease and their association with the aging process.

\section{Food and body culture}

Geertz $^{10}$ defines man as a being composed of the following overlapping levels: biological, social, cultural and psychological. As the man is analyzed, these levels are revealed and are very different 
from each other. The author suggests that by removing the cultural level, it's possible to access the structures of social organization which, in turn, offers the possibility of reaching the biological and psychological foundations.

It is believed that the concept of culture came about suddenly from man's ability to receive and transmit information. We become individual based on cultural patterns and meanings that we create to give meaning to life. These patterns form a set of notions that include religion, eating habits, symbols and several behavioral characteristics that contribute to the formation of the individual. ${ }^{10}$ However, culture is not something natural. It is essentially learned by immersion and imitation with members of the same group. ${ }^{11}$

Still for Concone, ${ }^{11}$ the perceived reality is necessarily mediated by cultural standards and immersion in culture is so automatic that "we only realize that we live immersed in one culture when we leave it to immerse into another" (p. 54).

Culture about the human body is much more than its pure and simple anatomy and physiology. It also includes beliefs related to the functioning of the organism and what it represents to society. The individual's health can be closely linked to beliefs, since certain actions on the body can have direct effects on health and disease. ${ }^{12}$

The autonomy of man brought the opportunity to develop cultures, among them, food culture. It is possible for man to manage his own life and control his organizations. In the food sphere, the human being has become able to make his own choices and elaborate different patterns throughout evolution, such as choosing foods in order to improve conditions and lifespan. ${ }^{13}$

Food has a direct association with social aspects, brings a volume of symbologies and demonstrates the relationship between humans, men and gods, as well as men and the environment. Society, in its turn, has something essential in food that organizes it. In this way, the beliefs and eating practices are difficult to modify even if they encounter the threshold of adequate nutrition. ${ }^{12}$ In addition to symbolism, food has become a demonstration of cultural differences and power relations, becoming a crucial element in distinguishing groups. ${ }^{14}$

Brazilian cuisine and, consequently, the food culture of the brazilians suffered a strong Portuguese, indigenous and African influence, main cultural matrices that shaped regional cuisines, in addition to other immigrants who settled down in the country. Food has a different meaning depending on its origin, culture and experiences, undergoing changes from childhood to old age. ${ }^{15}$ Most of the immigrant groups that came to Brazil brought, in addition to their food culture, clothing, behavior and family structure. These pillars ensure a sense of continuity for the people and are among the last features of immigrant culture that have disappeared over time. ${ }^{12}$

Socio cultural factors that influence diet can do so in ways that make it healthy or precarious. In the $50 \mathrm{~s}$, Castro ${ }^{16}$ already affirmed the precariousness of the Brazilian diet, understanding that dietary patterns were the result of socio-cultural factors, rather than geographical determinants. Portuguese immigrants brought with them in the 16th century the culture of a diet rich in various types of vegetables and fruits introduced by Arabs to Iberian Peninsula. However, the same habits could not be maintained, for example, wheat, which was not found in our lands and had to be replaced by cassava. It would be possible to develop the production of many vegetables here in Brazil during the colonization period, but Portuguese immigrants preferred to take their chance into the monoculture of sugar and gold extraction, as they generated fabulous profits. Therefore, they abandoned their polyculture and lowered their eating patterns. On the other hand, the creative force of our agriculture occurred by Africans coming on slave ships, in addition to the introduction of palm oil that saved entire groups from some hypovitaminosis.

\section{Food beliefs}

Food belief arises from the moment when the difference among food and non-food is defined. Vegetables that are considered food and medicine drugs can be extracted from the same soil, although they are also ingested. In this context, the term 'feeding' has a distinct definition of 'food'. The latter is any type of foodstuff, since 'feeding' means the nutritional property of foods. ${ }^{17}$

Still for Brandão, ${ }^{17}$ the sense of what is edible is even broader than that which is considered food. According to investigations carried out in the 1980s in the rural area of Goiás, farmers recognized a series of ingestible products that were not considered food. This category included water, coffee and alcoholic beverages. In an intermediate position between food and edibles, "what is put in food" (p. 98), were spices, oil, candy syrup and sauces.

In the same period of the aforementioned investigation, a different categorization of foods was made, as described by the author. Nature's food was determined: bush meat, fish, fruits, guariroba, pequi and honey; from pasture: meat from cattle; from the yard: poultry, pork, eggs, lard, fruits, vegetables, roots and coffee; from the fields: rice, corn, beans and cassava; of the city: salt, pasta, canned food, some other vegetables and candies. In the daily meal of the farmer, food had another type of classification. As 'mass': rice, beans, kassava, meat, potatoes, pasta; as 'mixture': vegetables; as 'sauce': spices and sauce seasoning.

Food had a category of cause and effect on the body or the biopsychic balance of those who consumed it. This classification had no scientific basis and was provided by some effect it caused after ingestion, without considering the individual's current state, levels of food contamination, preparation, conservation or shelflife. For Brandão: ${ }^{17}$

"There are several natural conditioners and the possibilities for symbolic manipulation in the relationship between the producer and nature, ruling the activities of cleaning, planting, carp, harvesting and preparing food, are multiple. There is no doubt that beliefs and principles of action are the framework of a wide system of projections of nature on the limits and modes of mediation of man as a food producer".

In a study carried out in London with Bangladeshi immigrants in the late $90 \mathrm{~s}$, a strong belief was demonstrated correlating diabetes mellitus (DM) and diet. The individuals were aware that refined sugar (sucrose) in excess was harmful, but believed that cane syrup - raw, liquid and dark - was considered safe. In addition to this contradictory demonstration, all vegetables that grow under the ground would be unsuitable for elderly, very young or very sick people. All individuals from the study believed that the onset and control of DM depended on the balance between what was consumed as food and what the body excreted, such as sweat, semen, urine and menstrual blood. Issues such as maintaining an adequate weight and physical activity practices were not significant for the sample studied, in a clear evidence that the belief in the binomial health-disease and food culture are not necessarily related to scientific findings (GREENHALGH; HELMAN; CHOWDHURY, 1998). 


\section{Religion and food}

Many food choices come up against the frontier of religion, even in groups derived from more secular ones. Hunger is an instinct that is difficult to control and is where religion finds its gap. It uses food as a method of discipline. While culture brought rules for action considered instinctive, religion reinforced the mechanism of hunger regulation as an extremely effective symbolic system. Religion shows the path of discipline in relation to food, when it comes to avoid gluttony - a deadly sin - or to regulate man's relationship with other living beings by promoting vegetarianism, or even the practice of animal sacrifice. Eating practices - or fasting - established by religion are far from nutritional or hygienic claims. They are intended for spiritual well-being and purification of the soul, although objectively, religion appropriates rules, including food rules as a measure of the individual's domestication, ${ }^{13}$ making food sacred or profane. Foods consumed at religious celebrations have more symbolic than nutritional significance, such as the wafer at Lord's Supper or the matzohat Jewish Passover (Pesach). ${ }^{12}$

Food bans are common as in Hinduism, where you cannot kill or consume any type of animal, especially cattle. In turn, the Islamic people are not allowed to eat pork and can only consume meat from ruminant animals with a cloven hoof, as long as the animal is sacrificed through ritual (halal meat), as well as fish consumption can only occur with those with fins and scales. Judaism, on the other hand, in addition to pork being prohibited, meat and milk or its derivatives cannot be consumed both in the same meal, as emphasized three times in the Old Testament: "You shall not boil a kid in its mother's milk". ${ }^{19-21}$ Ruminants with a cloven hoof can also only be consumed if sacrificed in a ritual called kosher. In the same way that religion can prohibit certain foods, it can also encourage the ingestion of others that can cause harm to health. ${ }^{12}$

Only over the centuries pork become a cursed animal, especially by the Hebrews. The initial reason would be that rare pork would transmit trichinosis, but the Hebrew people were not endowed with medical knowledge for such findings, in addition to the fact that meat from other animals could also transmit the same disease. But the explanation is also found in the Bible, however, without any medical connotation. The pig must be banned: "And the pig, though it has a split hoof completely divided, does not ruminate; consider it unclean. ${ }^{22}$ Other prohibitions without biological grounds were also cited, such as the ban on consumption of crawling reptiles, as it would be the result of a curse described in the book of Genesis, in punishing the serpent for having led Adam and Eve to disobey divine laws. ${ }^{23}$

Animal blood consumption is also prohibited when God grants Noah the right to eat animal meat:

"Everything that lives and moves about will be food for you. Just as I gave you the green plants, I now give you everything. But you must not eat meat that has its lifeblood still in it". ${ }^{24}$

\section{Nutrition related to health, longevity and disease prevention}

During ancient times, a period that ran from approximately 4000 $\mathrm{BC}$ to $476 \mathrm{AD}$, much was written about the relationship between food and health. Food Treaties were described by Hippocrates around the 5th-4th centuries BCand by Galen in the second century BC, to name a few. Along with pharmacology and surgery, dietetics is one of the three basic foundations of ancient medicine, but it was reserved only for those with purchasing power, as a means of prevention. For the less affluent, surgery and pharmacology remained to treat illnesses or to hasten death in the absence of a cure. Hippocrates already determined that the diet should be personalized according to factors such as age, sex and type of activity, assigning foods from arid and dry regions to those who needed more strength. ${ }^{14}$

Over the years, relationships between food consumption and health and disease characteristics of certain populations have been observed. From these relationships, it has been seen that people from some regions have a greater potential for longevity and a lower incidence of chronic diseases, such as the population in the Mediterranean region and those in Okinawa Province..$^{25,26}$

\section{Conclusion}

Food culture is an inseparable item of society. Different groups have different eating habits and beliefs and different ways of looking at the body and health, and they will never cease to exist. It is what identifies and differentiates people. It is therefore important to preserve these cultural components without the excessive desire to look younger, but also to adapt it so that its essence is maintained, in a way that also brings health benefits and contributes to longevity, regardless of the number of years ahead.

\section{Acknowledgments}

None.

\section{Conflicts of interest}

The authors declare have no conflict of interest about the publication of this paper.

\section{References}

1. Magalhães JP. The biology of aging: a primer. In: Stuart-hamilton, I. An introduction to gerontology. New York: Cambridge University Press, 2011;21-43.

2. Farinatti PTV. Teorias biológicas do envelhecimento: do genético ao estocástico. Rev Bras Med Esporte. 2002;8(4):129-138.

3. Cendoroglo MS, Filho CMA. Perfil dos centenários. In: Papaléo Netto M. et al. A Quarta Idade: o desafio da longevidade. São Paulo: Atheneu, 2015;55-61.

4. Kitadai FT, Papaléo Netto M. Influência Genética na Longevidade Humana. In: Papaléo Netto, M. et al. A Quarta Idade: o desafio da longevidade. São Paulo: Atheneu, 2015;01-11.

5. Guimarães RM, Camargos EF. Terapias Antienvelhecimento. In: Freitas EV. et al. Tratado de Geriatria e Gerontologia. Rio de Janeiro: Guanabara Koogan, 2.ed., 2006;1094-1099.

6. Papaléo Netto M, Kitadai FT. Desafios da longevidade: a quarta idade. In: Papaléo Netto M. et al. A Quarta Idade: o desafio da longevidade. São Paulo: Atheneu, 2015;13-24.

7. Papaléo Netto M, Vilas Boas CM. Evolução do processo de envelhecimento na quarta idade. considerações sobre formas de envelhecimento. In: Papaléo Netto M. et al. A Quarta Idade: o desafio da longevidade. São Paulo: Atheneu, 2015;25-34.

8. Souza CST. Origem da história da nutrição em gerontologia. In: Silva MLN. et al. Tratado de nutrição em gerontologia. São Paulo: Manole, 2016;3-10.

9. Santos LAS. O corpo, o comer e a comida. Salvador: EDUFBA, 2008;330p. 
10. Geertz C. O impacto cultural no conceito de homem. In: A interpretação das culturas.Rio de Janeiro: LTC, 1989;25-39.

11. Concone MHVB. A noção de cultura. Kairós Gerontologia. 2011;14(4):5166.

12. Helman CG. Cultura, Saúde \& Doença. Porto Alegre: Artmed, 4th edn. $2003 ; 408$.

13. Souza PR. Religião e comida. Como as práticas alimentares no contexto religioso auxiliaram na construção do homem. 2014. 181p. Dissertação (Mestrado em Ciências da Religião), Pontifícia Universidade católica de São Paulo, São Paulo.

14. Flandrin JL, Montanari M. História da alimentação. São Paulo: Estação Liberdade, 1998;885.

15. Pontin RHO. significado da alimentação para idosas negras do grupo Mariama: um novo olhar. Dissertação (Mestrado em Gerontologia Social), Pontifícia Universidade Católica de São Paulo, São Paulo. 2005;125.

16. Castro J. Ensaios de Geografia Humana. São Paulo: Brasiliense, 1957;280.

17. Brandão CR. Crenças de uso e restrições de consumo: a ideologia das relações entre o consumidor e o alimento. Plantar, Colher, Comer. Um estudo sobre o campesinato goiano. Rio de Janeiro: Graal, 1981;95-137.

18. Greenhalgh T, Helman C, Chowdhury AM. Health beliefs and folk models of diabetes in British Bangladeshis: a qualitative study. BMJ. 1998;316:978-983.
19. Bible OT. Exodus. portuguese. bíblia sagrada. petrópolis: vozes, 2nd.edn., 2006;23:19.

20. Bible OT. Exodus. Portuguese. Bíblia sagrada. Petrópolis: Vozes, 2nd. edn., 2006;34:26.

21. Bible OT. Deuteronomy. Portuguese. Bíblia sagrada. Petrópolis: Vozes, 2nd.edn. 2006;14:21.

22. Bible OT. Leviticus. Portuguese. Bíblia sagrada. Petrópolis: Vozes, 2nd. edn., 2006;11:7.

23. Bible OT. Genesis. Portuguese. Bíblia sagrada. Petrópolis: Vozes, 2nd. edn. 2006;3:14.

24. Bible OT. Genesis. Portuguese. Bíblia sagrada. Petrópolis: Vozes, 2nd. edn, 2006;.9:.3-4.

25. Trichopoulou A. et al. Definitions and potential health benefits of the mediterranean diet: views from experts around the world. $B M C \mathrm{Med}$. 2014;12(112):1-16.

26. Gavrilova S, Gavrilov LA. Comments on dietary restriction, Okinawa diet and longevity. Gerontology. 2012;58(3):221-223. 